\title{
Diversification of Luzula sect. Luzula (Juncaceae) on the Balkan Peninsula - a cytogenetic approach
}

\author{
Tinka Bačič • Božo Frajman • Jasna Dolenc Koce
}

Received: 9 December 2014 / Accepted: 26 January 2016/Published online: 21 April 2016

(C) The Author(s) 2016. This article is published with open access at Springerlink.com

\begin{abstract}
Luzula sect. Luzula is one of the taxonomically most intricate groups of angiosperms, where diversification is mostly driven by true polyploidy and agmatoploidy (fission of chromosomes) leading to three different karyotypes (whole chromosomes - AL, halfsized chromosomes - BL and quarter-sized chromosomes - CL). Morphologically, the taxa are often difficult to distinguish, and genome size data coupled with karyological investigations are currently the most reliable means for their identification. For the Balkan Peninsula, one of the botanically least studied areas of Europe, ten taxa from this section have been reported, but little is known about their distribution. We here estimated the nuclear DNA amount (genome size, GS) using interphase-peak DNA image cytometry and counted the chromosomes for 33 populations of five species of Luzula sect. Luzula mostly from mountainous areas of the Balkan Peninsula and the adjacent southeastern Alps. Five taxa have been confirmed, of which $L$. divulgatiformis is new for Croatia and $L$. exspectata for Macedonia and Serbia. The most common species in the Dinaric mountains appears to be diploid $(2 \mathrm{n}=12 \mathrm{AL})$ L. taurica, for which the
\end{abstract}

T. Bačič · J. Dolenc Koce

Department of Biology, Biotechnical Faculty, University of Ljubljana, Večna pot 111, SI-1000 Ljubljana, Slovenia

T. Bačič

e-mail: martina.bacic@bf.uni-lj.si

B. Frajman $(\bowtie)$

Institute of Botany, University of Innsbruck, Sternwartestraße 15, A-6020 Innsbruck, Austria

e-mail: bozo.frajman@uibk.ac.at
GS $(2 \mathrm{C}=0.83 \mathrm{pg}$ DNA, fitting well in the range of previously determined values of diploid taxa) has been determined for the first time. The GS and karyotypes of other taxa (L. campestris, L. divulgatiformis, L. exspectata, L. multiflora subsp. multiflora) correspond well to previously published values. An identification key for the Balkan taxa of Luzula sect. Luzula is also included.

Keywords agmatoploidy. Balkan Peninsula . chromosome counts · genome size - identification key . Luzula $\cdot$ polyploidization

\section{Introduction}

The evolution of plants, especially of angiosperms, is characterized by numerous polyploidization events (Soltis et al. 2009) that significantly contributed to their diversification and radiation (Wood et al. 2009; Husband et al. 2013; Madlung 2013), as they enable almost instantaneous speciation (Weiss-Schneeweiss et al. 2013). Two types of polyploidy can be recognized from a genetic point of view. Autopolyploids arise within a single population or among ecotypes of a single species whereas allopolyploids are derived from interspecific hybrids (Ramsey and Schemske 1998). The genome size (GS) of polyploids is expected to increase in direct proportion with ploidy level, even if in some polyploid groups a significant decrease of monoploid GS, termed genome downsizing (Verma and Rees 1974; Renny-Byfield et al. 2013), can be observed. Contrary to true polyploidy, in some cases the increase in 
chromosome number is not correlated with an increase of genome size, a phenomenon named agmatoploidy (Malheiros and Gardé 1950; Löve et al. 1957); instead, the nuclear DNA amount is retained (Mello-Sampayo 1961; Bačič et al. 2007a). Agmatoploidy is based on fission of holocentric (holokinetic) chromosomes, which possess diffuse kinetochores spread along the chromatids and lack primary constrictions (Luceño and Guerra 1996; Haizel et al. 2005; Nagaki et al. 2005; Heckmann et al. 2011; Bozek et al. 2012; Melters et al. 2012; Heckmann et al. 2013). The phenomenon has been observed in animals and several angiosperm lineages (for a review, see Melters et al. 2012), e.g. Carex (Löve et al. 1957; Hipp et al. 2009), Cuscuta (Pazy and Plitmann 1995), Drosera (Melters et al. 2012) and Luzula (Nordenskiöld 1951; Bozek et al. 2012).

Luzula DC. (Juncaceae) comprises ca 115 species distributed throughout the world. The most variable and taxonomically diverse group within the genus is Luzula sect. Luzula with 57 taxa worldwide, of which almost twenty occur in Europe, one of the richest diversity centres of the section (Kirschner 2002; Drábková et al. 2003). The diversification of this group is mainly based on karyological differentiation, founded on both agmatoploidy and true polyploidy (Malheiros and Gardé 1950; Nordenskiöld 1951; Bačič et al. 2007a; Bozek et al. 2012). Due to agmatoploidy, the taxa of the genus Luzula have chromosomes of three different sizes. The largest, full-size chromosomes are designated as AL-type, the intermediate, half-size chromosomes as BLtype and the smallest, quarter-size chromosomes as CL-type (Nordenskiöld 1951; Bozek et al. 2012). The change of chromosome number due to agmatoploidy (partial and complete) provides effective genetic isolation and abrupt speciation at the diploid level (Nordenskiöld 1951, 1956; Kirschner 1992a,b; Bozek et al. 2012). Agmatoploid chromosome sets are then carried to higher ploidy levels through allopolyploidy (Kirschner 1992a).

Morphologically, the taxa within the section are difficult to distinguish. The poor morphological differentiation is an obstacle to chorological, phytosociological and ecological investigations and is also one of the reasons why cytogenetic as well as phylogenetic studies of Luzula sect. Luzula are scarce (but see e.g. Drábková et al. 2003, 2006). Bozek et al. (2012) recently combined cytological and phylogenetic data and showed that different mechanisms of karyotype evolution operate in different lineages of Luzula. However, the recent description of two new species from Central Europe, L. divulgatiformis Bačič \& Jogan and L. exspectata Bačič \& Jogan (Bačič et al. 2007a) clearly shows that the diversification of the group is poorly understood and needs more attention. Moreover, the precise distribution of the taxa, both due to the description of the new species and common misidentifications (Bačič et al. $2007 b$ ) is insufficiently known, especially for botanically less explored regions of Europe.

The Balkan Peninsula belongs to the botanically least explored regions of Europe even if it is probably Europe's floristically richest area (Frajman et al. 2014) harbouring about 6,500 species of which more than one third (ca 2,600 to 2,700) are endemic and about 400 are considered local endemics (Horvat et al. 1974; Kryštufek and Reed 2004; Stevanović et al. 2007; Tomović et al. 2014). Several new species have been described from the Balkans in the last decade (see Frajman et al. 2014 for a review), and several new localities of rare or overlooked species have been discovered (e.g. Frajman and Schönswetter 2008; Mullaj et al. 2010; Frajman and Bačič 2011; Milanović et al. 2011; Barina et al. 2011, 2013; Frajman et al. 2013; Frajman et al. 2014). Last but not least, an ever increasing number of phylogenetic and phylogeographic (e.g. Frajman and Oxelman 2007; Stefanović et al. 2008; Frajman and Schneeweiss 2009; Kučera et al. 2010; Surina et al. 2011; Lakušić et al. 2013; Kutnjak et al. 2014; Rešetnik et al. 2014; Surina et al. 2014) as well as cytogenetic studies (e.g. Bogunić et al. 2003, 2011a,b; Siljak-Yakovlev et al. 2005, 2008, 2010; Muratović et al. 2010; Sánchez-Jiménez et al. 2012; Niketić et al. 2013) shows complex diversification patterns in this area.

For the Balkan Peninsula, at least eight taxa from Luzula sect. Luzula have been reported by Kirschner (2002; Table 1). In addition, two recently described complete agmatoploid taxa $L$. divulgatiformis and L. exspectata have also been discovered in the northernmost parts of the Balkan Peninsula in Slovenia (Bačič et al. 2007a; Frajman and Bačič 2012) and are expected to occur also in other parts of the Balkans taking into account their known distribution and ecology. Some of the taxa have only been reported for a few localities and some reports are based only on morphological inspection, and are thus unreliable.

So far, GS was estimated for $L$. abyssinica Parl. (Šmarda et al. 2014), L. alpina Hoppe (Bačič et al. 2007a), L. campestris (L.) DC. (Sen et al. 1990; Mukherjee et al. 1993; Bačič et al. 2007a; Bozek et al. 2012), L. divulgata 
Table 1 Taxa of Luzula sect. Luzula with respective karyotypes reported for the Balkan Peninsula (Kirschner 2002, Bačič et al. 2007a,b, Frajman and Bačič 2012).

\begin{tabular}{ll}
\hline Taxon & Karyotype \\
\hline L. campestris, L. pallescens, L. taurica & $12 \mathrm{AL}$ \\
L. divulgata, tetraploid L. multiflora subsp. & $24 \mathrm{AL}$ \\
$\quad$ multiflora & \\
hexaploid L. multiflora & $36 \mathrm{AL}$ \\
L. divulgatiformis, L. exspectata, L. fallax & $24 \mathrm{BL}$ \\
L. sudetica & $48 \mathrm{CL}$ \\
L. multiflora subsp. snogerupii & $12 \mathrm{AL}+24 \mathrm{BL}$ \\
\hline
\end{tabular}

Kirschner (Bačič et al. 2007a), L. divulgatiformis (Bačič et al.2007a), L. exspectata (Bačič et al. 2007a), L. multiflora (Ehrh.) Lej. (Barlow and Nevin 1976; Kuta et al. 2004; Bačič et al. 2007a; Bozek et al. 2012), L. pallescens Sw. (Mello-Sampayo 1961; Halkka 1964) and L. sudetica (Willd.) Schult. (Mukherjee et al. 1993; Bačič et al. 2007a; Bozek etal. 2012). Most of these species are also listed in the Plant DNA C-values database (Bennett and Leitch 2012).

Taking into account the morphological similarity of the taxa and common misidentifications, our aim is to contribute to the knowledge of the distribution of mostly mountain-dwelling taxa from Luzula sect. Luzula on the Balkan Peninsula using reliable characters, i.e. karyotype and GS data, which are crucial for identification. We focus mostly on the mountainous areas of the Balkan Peninsula but include also the adjacent southeastern Alps. We provide new GS and karyological data and contribute additional evidence for an agmatoploid origin of certain karyotypes. An identification key for Balkan species is provided.

\section{Material and methods}

Plant material

Samples of plants and seeds from populations of Luzula sect. Luzula were collected in Slovenia, Croatia, Bosnia and Herzegovina, Serbia, Kosovo, Montenegro, Albania, Macedonia, and Bulgaria in years 20052012. In total, 33 populations and up to 10 individuals per population were investigated. Herbarium vouchers of the examined populations are deposited in the herbarium of the University of Ljubljana (LJU). The plants were determined using determination keys and other literature relevant to the area studied (e.g. Kirschner 1993, 1994, 2002; Bačič et al. 2007b). The determinations were verified with karyological analyses. Additionally, two samples of L. divulgatiformis (B23 and S24) and two of L. taurica (V.I. Krecz.) Novikov (B24 and B25), reliably determined on morphological basis only, were included in the distribution map. A list of the samples and their localities is given in Appendix 1, and their distribution is shown in Fig. 1, where also the localities of Balkan populations with the exceptions of the common lowland species L. campestris and L. multiflora, studied by Kirschner (1992a, 2002) and Bačič et al. (2007a,b), are mapped.

Chromosome numbers and genome size measurement

Seeds were germinated in Petri dishes until the roots were at least $3 \mathrm{~mm}$ long. Root tips of young seedlings were fixed, stained and squashed to prepare microscopic slides, as previously described in Bačič et al. (2007a). Briefly, root tips were fixed in $4 \%$ phosphate-buffered neutral formaldehyde at room temperature and postfixed in 3:1 methanol : acetic acid at $4^{\circ} \mathrm{C}$. Fixed root tips were hydrolysed in $5 \mathrm{~N} \mathrm{HCl}$ for $90 \mathrm{~min}$ at $20^{\circ} \mathrm{C}$ and stained with Feulgen reagent. Stained root tips were washed in several changes of $\mathrm{SO}_{2}$-water, and squash preparations of dissected root meristems were prepared in $45 \%$ acetic acid. Nuclear DNA amount (C-value) was measured densitometrically by interphase-peak DNA image cytometry (Vilhar et al. 2001), using an Axioscope MOT light microscope (Carl Zeiss, Germany) with a $63 \times$ oil immersion objective, CCD camera (Sony DXC-950P), frame grabber (Matrox Meteor), PC and the KS 400 ver. 3.0 image analysis software package (Carl Zeiss, Germany). The image analysis system was densitometrically calibrated prior to each set of measurements, and integrated optical density (IOD) was measured for approximately 200 interphase nuclei per slide.

Pisum sativum cv. 'Kleine Rheinländerin' $(2 \mathrm{C}=$ 8.84 pg DNA, Greilhuber and Ebert 1994) was used as the calibration standard to convert arbitrary units of IOD to pg DNA. Pisum sativum root tips were processed simultaneously with the Luzula specimens during all experimental procedures. The amount of DNA in the unreplicated (G1 phase) nuclei was expressed as $2 \mathrm{C}$ values; for simplicity, we hereafter apply the term genome size (GS) to these values. The same slides were 


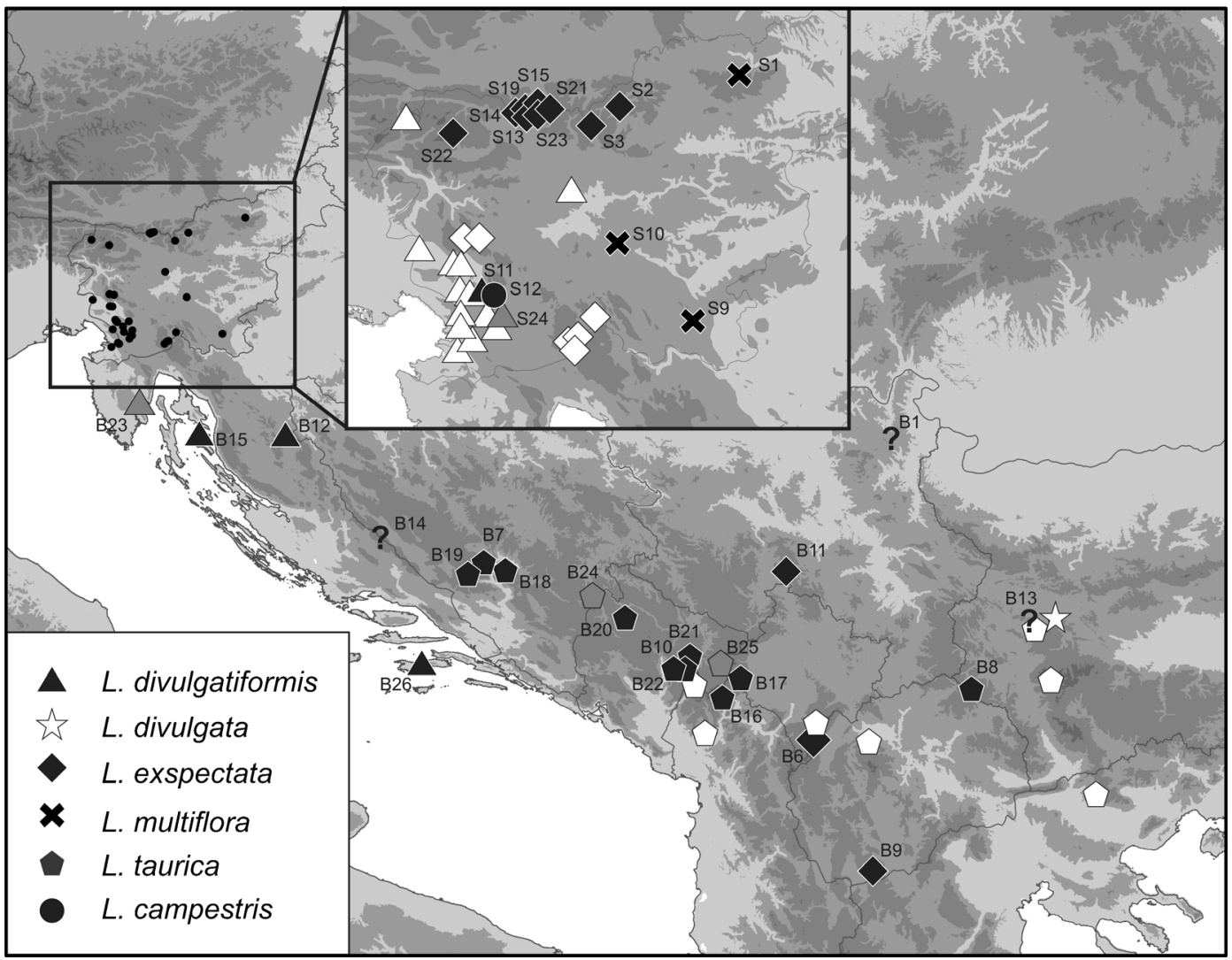

Fig. 1 Sampled populations of Luzula sect. Luzula complemented with literature data for the Balkan Peninsula (black karyologically investigated samples, grey - morphologically investigated herbarium samples, white - Kirschner 1992a, 2002,

used to determine the number and type of chromosomes. The mean size of metaphase chromosomes was calculated from the 4C-value divided by the chromosome number. Chromosomes with a size $>90 \mathrm{fg}$. were designated as AL-type and chromosomes ranging from 45 to $90 \mathrm{fg}$. as BL-type. Statistical analyses were performed with Microsoft Excel and Prism 3.02 (GraphPad) software.

\section{Results}

Four karyotypes corresponding to five different taxa were determined for the 33 populations analysed (Table 2, Fig. 3). Most of the populations belonged to L. exspectata (12) and L. taurica (10) whereas other taxa were represented by a single or only a few samples. Chromosomes of L. campestris, L. taurica and L. multiflora were designated as AL-type, while chromosomes of $L$. divulgatiformis and $L$. exspectata were half the size and were designated as BL-type (Table 2).
Bačič et al. 2007a,b). Literature data for the most common species L. campestris and L. multiflora were not included. Population identifiers correspond to Appendix 1.

The average size of all AL chromosomes in the study was $144.63 \mathrm{f}$. DNA. The average size of the BL chromosomes was $48 \%$ of the size of the AL chromosomes (Table 1). Two ploidy levels were revealed. The standard diploid chromosome set $2 \mathrm{n}=12 \mathrm{AL}$ was found in L. campestris and L. taurica (Fig. 2). The other diploids were agmatoploid $L$. divulgatiformis and $L$. exspectata with $24 \mathrm{BL}$ and unidentified taxa (samples B1, B13 and B14) also with approximately 24 BL (see the Discussion for details). The hexaploid L. multiflora possessed 36 AL chromosomes (Figs. 2).

Luzula exspectata is new for Macedonia and Serbia at a distance of more than $500 \mathrm{~km}$ from previously known populations in Slovenia (Fig. 1). In the Dinaric Mountains between these two areas, L. taurica appears to be the most common species in the (sub)alpine belt on calcareous substrates. Luzula divulgatiformis is new for Croatia, thus extending its known distribution range towards the south.

The estimated GS corresponded well to the ploidy levels (Table 2, Fig. 3). The GS of diploids ranged from 0.66 to 
Table 2 Karyotype and genome size of investigated samples of Luzula sect. Luzula. The karyotype is described by chromosome number and type (AL - full size chromosome, $\mathrm{BL}$ - half size chromosome, $\mathrm{CL}$ - quarter size chromosome). The $2 \mathrm{C}$-value is presented as mean value $\pm S E$ of all populations of a certain species; $C V$ - coefficient of variation.

\begin{tabular}{lllllll}
\hline Species & Number of populations & Karyotype & Ploidy level & 2C-value (pg DNA) & CV [\%] & Chromosome size [fg DNA] \\
\hline L. campestris & 1 & $12 \mathrm{AL}$ & $2 \mathrm{x}$ & 0.92 & - & 153.33 \\
L. taurica & 10 & $12 \mathrm{AL}$ & $2 \mathrm{x}$ & $0.83 \pm 0.01$ & 5.36 & 138.33 \\
L. divulgatiformis & 4 & $24 \mathrm{BL}$ & $2 \mathrm{x}$ & $0.83 \pm 0.06$ & 10.64 & 70.00 \\
L. exspectata & 12 & $24 \mathrm{BL}$ & $2 \mathrm{x}$ & $0.83 \pm 0.02$ & 7.84 & 69.17 \\
L. multiflora & 3 & $36 \mathrm{AL}$ & $6 \mathrm{x}$ & $2.56 \pm 0.08$ & 5.70 & 142.22 \\
\hline
\end{tabular}

1.03 pg DNA. Luzula taurica, L. divulgatiformis and L. exspectata had the same GS (mean $2 \mathrm{C}=0.83 \mathrm{pg}$ DNA) whereas $L$. campestris had a slightly higher value (0.92 pg DNA). The hexaploid L. multiflora had approximatly triple GS (mean $2 \mathrm{C}=2.56 \mathrm{pg}$ DNA, ranging from 2.36 to $2.78 \mathrm{pg}$ DNA) of the diploids.

Based on previously published records regarding the presence of taxa from Luzula sect. Luzula on the Balkan Peninsula as well as our experiences with herbarium revisions, we compiled an identification key (Appendix 2) for Balkan taxa, mostly following Bačič et al. (2007b) and Kirschner (1993, 2002). Shape of the

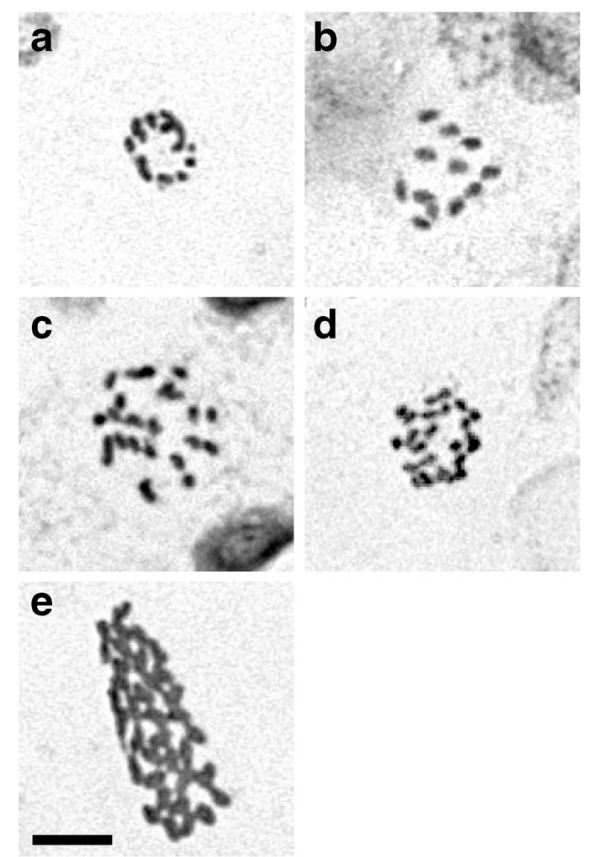

Fig. 2 Metaphase or late prophase chromosomes of investigated taxa of Luzula sect. Luzula. a - L. campestris (12 AL), b L. taurica (12 AL), c - L. divulgatiformis (24 BL), d L. exspectata (24 BL), e - L. multiflora (36 AL). The bar represents $5 \mu \mathrm{m}$. seeds and their appendages, which are important for identification of Luzula species, are shown in Fig. 4.

\section{Discussion}

Luzula sect. Luzula on the Balkan Peninsula

The morphological inspection of collected samples coupled with karyological analysis revealed that most of the populations under study belong to $L$. exspectata and L. taurica (Fig. 1, Table 2). The occurrence of L. exspectata in the southeastern Alps (Julijske Alpe, Karavanke and Kamniške Alpe) was not surprising, as this species was recently described from the Julijske Alpe in Slovenia and reported for adjacent areas in Slovenia, Austria and Italy (Bačič et al. 2007a,b). In the past, it was mostly confused with L. multiflora or L. sudetica, but extensive morphological and karyological analyses have shown that it is a separate species with $24 \mathrm{BL}$ chromosomes, which arose from the diploid level via complete agmatoploidy (Bačič et al. 2007a). In the Alps, it is confined to locally oligotrophic, humusrich patches on calcareous substrate (Bačič et al. 2007a). Our additional localities published here show that this taxon is the most common (sub)alpine species on calcareous substrates in the southeastern Alps; also, the only known populations of $L$. exspectata from the northernmost Balkan Peninsula (Mt Snežnik in Slovenia, Bačič et al. 2007a,b and Babno polje, Frajman and Bačič 2012) had similar ecology. It is therefore surprising that the samples from the Western Balkan countries of Macedonia and Serbia analysed in this study, which morphologically and karyologically corresponded to L. exspectata, grew on a siliceous substrate. The newly discovered localities are more than $500 \mathrm{~km}$ away from the previously known populations (Fig. 1), and it is 


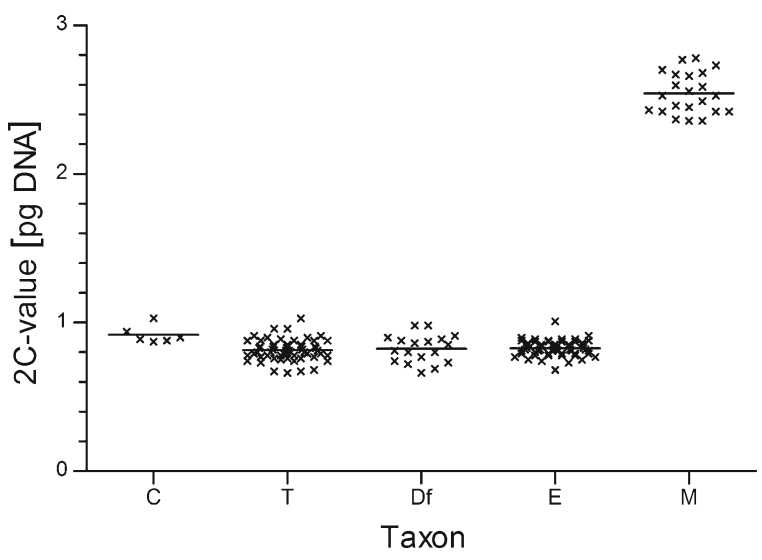

Fig. 3 Genome size (2C-value) of investigated taxa of Luzula sect. Luzula. Each cross represents a 2C-value measured in 100200 interphase nuclei of a single Luzula root tip and calibrated to Pisum sativum root tips. Lines represent mean 2C-values for each taxon. The number of measured root tips $(n)$ for each species is given in parenthesis. $\mathbf{C}-L$. campestris $(n=6), \mathbf{T}-$ L. taurica $(n=$ 56), $\mathbf{D f}-L$. divulgatiformis $(n=18), \mathbf{E}-L$. exspectata $(n=56), \mathbf{M}$ -L. multiflora $(n=22)$.

surprising that $L$. exspectata was not found in the mostly calcareous Dinaric Mountains in between where all samples from similar habitats belonged to $L$. taurica. Based on karyotype and distribution, the Balkan populations were expected to belong to L. fallax Kirschner $(2 \mathrm{n}=24 \mathrm{BL})$, which was previously reported for 'slopes and hills and lower mountains and meadows on naturally or artificially disturbed acid soils' in Albania, Bulgaria, Greece and European parts of Turkey (Kirschner 2002). Morphologically, however, this species is well characterized by its small, few-flowered, usually hemispherical clusters, papillose peduncles and relatively short seed appendages (Kirschner 2002), which was not the case with our Balkan samples. They were morphologically similar to L. exspectata, having ovoid to elongated, medium-sized clusters with more than ten flowers per cluster, smooth peduncles and conspicuous appendages (Bačič et al. 2007b). Further detailed morphological and molecular phylogenetic studies are needed to reveal whether the Balkan populations are indeed conspecific with L. exspectata from the Alps and whether L. exspectata also occurs in the calcareous Dinaric Mountains.

Luzula taurica $(2 \mathrm{n}=12 \mathrm{AL})$ was the most common true diploid in our study, being sampled from Bosnia and Herzegovina across Montenegro to Albania, Kosovo and Macedonia (Fig. 1). Almost all populations were from the Dinaric Mountains, except the Macedonian sample from Mt Rujen (B8) on the border with Bulgaria. This, as well as the southeastern-most Dinaric populations from Mt Gjeravica/Đeravica in Kosovo (B17) and from the Trešnjevik saddle (B21) and Čakor pass (B25) in Montenegro were growing on acidic meadows on siliceous substrates whereas all other plants grew on locally oligotrophic, humus-rich patches on calcareous (sub)alpine meadows and pastures thus sharing the ecology with Alpine populations of $L$. exspectata. Also, previously identified populations from the Balkan Peninsula (Kirschner 2002) were growing in subalpine grasslands. Based on Fig. 1, we can conclude that L. taurica is likely the most common (sub)alpine species from Luzula sect. Luzula on the Balkan Peninsula.

Another interesting although expected discovery is the occurrence of $L$. divulgatiformis in Croatia (Fig. 1). This agmatoploid species $(2 \mathrm{n}=24 \mathrm{BL})$ was recently described from Slovenia where it grows in open woodlands, forest edges and clearings, mostly in lowlands
Fig. 4 Shape of seeds and their appendages of Luzula sect. Luzula. a - Luzula campestris, b - Luzula divulgata, c - Luzula expectata, $\mathbf{d}$ - Luzula sudetica.

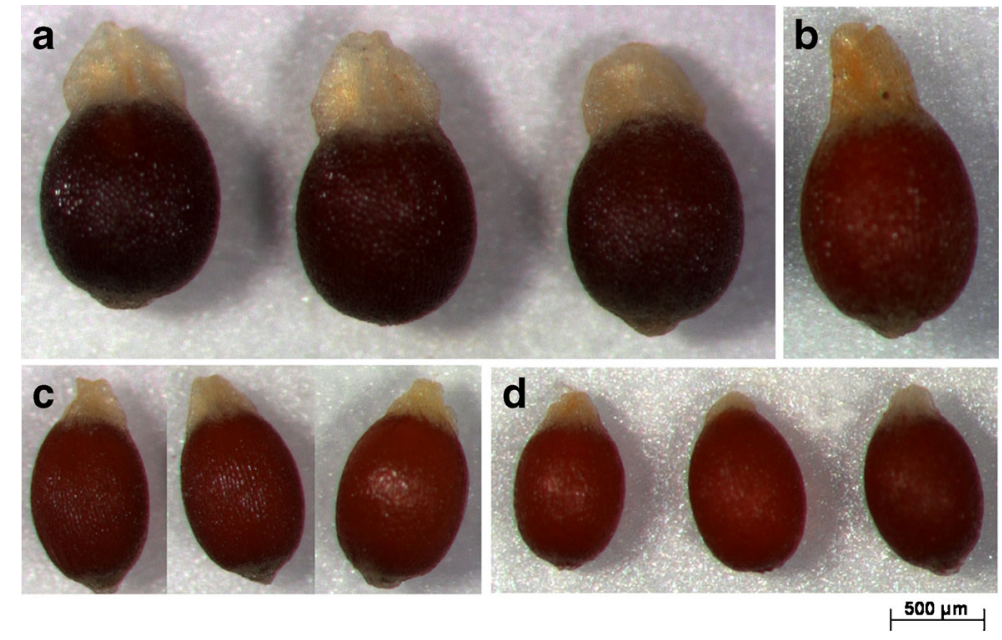


(Bačič et al. 2007a,b). In this study, an additional population (S11) from the Kras area in SW Slovenia, from where several populations have been reported (Bačič et al. 2007a,b; Fig. 1), was investigated karyologically, in addition to one from Mt Vremščica (S24), which was based on a herbarium voucher alone. The karyologically investigated Croatian populations from Rab Island (B15) and Pelješac (B26) as well as one morphologically investigated herbarium voucher (Labin area in Istria, B23) were from the Adriatic coast. As the plants collected at Plitvička jezera (B12, NW Croatia) were in a fairly late phenological stage, additional sampling would be needed for final confirmation of the determination. The distribution of L. divulgatiformis (Fig. 1) is, according to current knowledge, limited to SW Slovenia, NW Croatia and the coastal part of Croatia, but its occurrence is expected also in adjacent Italy and on the Adriatic coast further south. The species is thermophilous, mostly thriving in nutrientpoor karstic meadows, pastures, scrublands and forest edges.

Lowland diploid L. campestris $(2 \mathrm{n}=12 \mathrm{AL})$ and hexaploid L. multiflora $(2 \mathrm{n}=36 \mathrm{AL})$ were collected in the lowlands of the northernmost Balkan Peninsula (Slovenia) where both species are common, the former thriving in dry meadows whereas the latter prefering moist habitats, mostly meadows and forests (Bačič et al. 2007b). Both species are likely common in lowland areas of the Balkan Peninsula (Kirschner 1993, 2002), but as our focus was on mountainous areas, no populations of these species were sampled and therefore also the literature data of both are not included in Fig. 1. Also, no population of tetraploid L. multiflora, thriving in the Pyrenees, Massif Central, Alps and Tatra Mts (Kirschner 1996), have been found on the Balkan Peninsula. The tetraploid L. multiflora subsp. snogerupii Kirschner $(2 n=12 \mathrm{AL}+24 \mathrm{BL})$, which was reported for grassy mountain slopes above $1,000 \mathrm{~m}$ in Bulgaria and Greece (Kirschner 2002), also remained unconfirmed.

Moreover, two other species from Luzula sect. Luzula reported from the Balkan Peninsula were not sampled. The diploid L. pallescens $(2 \mathrm{n}=12 \mathrm{AL})$ is scattered in Eurasia and North America (Kirschner 2002). The only reliable record from the Balkan Peninsula is from Fojnica in Bosnia and Herzegovina; the majority of old literature data are erroneous due to confusion with pale-flowered forms of $L$. multiflora (Kirschner 2002). This was also the case in Slovenia where the species is absent (Bačič et al. 2007b). On the other hand, L. sudetica $(2 \mathrm{n}=48 \mathrm{CL})$, which is reported for the mountains of the Balkan Peninsula (Kirschner 2002), was not among our samples. Luzula sudetica appears to be absent in Slovenia (Bačič et al. 2007a). Certainly, additional field sampling is needed in the Balkans to reveal where this taxon is present as well as to get more reliable data about the distribution of other taxa from this intricate group of plants.

In three Balkan populations, the combination of morphological characters and karyological analysis was puzzling. Sample B1 from Serbia (Mt Stol) is diploid with ca $24 \mathrm{BL}$ chromosomes (the accurate number could not be assessed). The morphological characteristics were intermediate: relatively ovoid-subglobular seeds and very long appendages indicate $L$. campestris or L. divulgata, and papillose peduncles of clusters are characteristic for L. fallax (also karyotype!), but other characters (short style, anther/filament ratio approximately $1: 1$ ) indicate L. multiflora s.str. It might be that the sample was of a hybrid origin, as already Kirschner (1992c) suggested that L. fallax shows a tendency to hybridize. Samples B13 from Bulgaria (Mt Vitosha) and B14 from Bosnia and Herzegovina (Mt Troglav) were also diploid with $2 \mathrm{C}=0.90 \mathrm{pg}$ DNA. The accurate number of chromosomes could not be assessed for the former, which possessed many more than $12 \mathrm{BL}$ chromosomes, whereas the latter had $24 \mathrm{BL}$ chromosomes. Morphologically, the plants resembled L. taurica (oblong-ovoid seeds, long styles and long anthers), which, however, has $12 \mathrm{AL}$ chromosomes and was reported for Mt Vitosha by Kirschner (1993). It is possible that fission of chromosomes occasionally occurs in L. taurica and that our samples are merely its agmatoploid cytotype. Further sampling as well as karyological and molecular phylogenetic investigations are needed to finally determine these populations and to get further insights into the diversification of Luzula sect. Luzula on the Balkan Peninsula. Taking into consideration the group's taxonomical intricacy as well as the insufficient knowledge of the flora of the Balkan Peninsula, we expect that some new species of Luzula might also be discovered there in the future.

Genome size and chromosome numbers

So far, genome size has been measured for only about $20 \%$ of the Luzula species (Bennett and Leitch 2012). In Luzula sect. Luzula with 57 species, genome size was estimated for eight taxa (Bennett and Leitch 2012). The present study provides the first genome size data for 
L. taurica and presents additional estimates for four species (L. campestris, L. divulgatiformis, L. exspectata and L. multiflora; Table 2).

The GS of the investigated samples ranged from 0.66 to 2.78 pg DNA and was distributed discretely (Fig. 3, Table 2), corresponding to the ploidy levels revealed by chromosome counts. The average GS of all diploids was $0.85 \mathrm{pg}$ DNA, and average GS of the hexaploid was 2.56 pg DNA. In general, the measured GS corresponded well to the previously published results obtained by DNA image cytometry (Bačič et al. 2007a) and flow cytometry (Bozek et al. 2012).

Our study provides first GS estimates for L. taurica, based on 56 samples from 10 populations (Table 2, Appendix 1). The GS of L. taurica (0.83 pg DNA) fits well in the range of other diploids from sect. Luzula, analysed here or previously (Bačič et al. 2007a; Bozek et al. 2012), whose GS ranged from 0.83 pg DNA in L. divulgatiformis to $0.97 \mathrm{pg}$ DNA (obtained by image cytometry) / 1.14 pg DNA (obtained by flow cytometry) in L. campestris.

The newly determined $2 \mathrm{C}$-values of $L$. campestris (0.92 pg DNA), L. divulgatiformis (0.83 pg DNA), L. exspectata (0.83 pg DNA) and L. multiflora (2.56 pg DNA) are comparable to the values $(0.97$, $0.82,0.96$ and $2.71 \mathrm{pg}$ DNA, respectively) published by Bačič et al. (2007a) and Bozek et al. (2012; 0.82 for L. campestris and $2.54 \mathrm{pg}$ DNA for L. multiflora). By contrast, our estimates for L. multiflora are about $17 \%$ higher than that $(3.034 \mathrm{pg})$ obtained by Kuta et al. (2004), but the difference is likely due to the different methodology (densitometry vs flow cytometry) or the usage of different plant tissues. On the other hand, the about three to four times higher GS reported for L. campestris by Mukherjee et al. (1993) and Sen et al. (1990) is possibly caused by misidentification, and their samples likely belong to a polyploid taxon, maybe to the common lowland species L. multiflora.

\footnotetext{
Acknowledgements We would like to thank Andreja Čurman for the laboratory measurements of the $2 \mathrm{C}$ values, Peter Schönswetter, Špela Novak, Sandro Bogdanović, Martin Turjak, Denis Kutnjak and Simona Strgulc Krajšek for collecting Luzula plants and seeds. Peter Schönswetter contributed valuable comments on an earlier version of the manuscript. We are grateful to the associate editor and two anonymous reviewers for valuable comments. This work was in part supported by the Slovenian Research Agency (programme group P1-0212/1.03). The authors declare that the experiments comply with the laws of Slovenia.
}

Appendix 1 List of samples with locality, ecology and collection data.

BF - Božo Frajman, DK - Denis Kutnjak, MT - Martin Turjak, PS - Peter Schönswetter, ŠN - Špela Novak.

\section{Luzula campestris}

S12: Slovenija, Primorska, Kras, between the villages Dobravlje and Kazlje, 325 m, $13.89333^{\circ}$ E, 45.76556 N, BF 12582, 2.6.2009.

\section{Luzula divulgatiformis}

B12: Croatia, Plitvićka jezera lakes, SE of Repušnica (S of Kapela Korenička), NE of Štetina draga, 710 m, 15.6778 ${ }^{\circ} \mathrm{E}, 44.7889^{\circ} \mathrm{N}, \mathrm{BF}$ and PS $11480,14.7 .2006$; B15: Croatia, island Rab, Lopar, $14.7247222^{\circ} \mathrm{E}$, 44.8397222 ${ }^{\circ} \mathrm{N}, \mathrm{BF} 12753,4.6 .2010$;

B23: [Croatia, Istria], Šumber (ca 9 km NNW Labin): nächste Umgebung des Weilers; Wiesen und Raine, Magerrasen, H. and W. Gutermann 36346, 20.5.2001 (sub L. multiflora);

B26: Croatia, Adriatic coast, Pelješac, Sv. Ilija, in the Pinus nigra forest, ca $600 \mathrm{~m}$ a.s.l., S. Bogdanović, 17. 6. 2012 (ZAGR, 32150);

S11: Slovenia, Primorska, Kras, between the villages Dobravlje and Kazlje, 325 m, $13.89333^{\circ}$ E, 45.76556 N, BF 12583, 2.6.2009;

S24: [Slovenia, Primorska], Vremščica S Senožeče, Nordflanke knapp unter dem Gipfel, Halbtrockenrasen und Säume, 1,000-1,025 m, W. Gutermann 28000, 3.6.1994 (sub L. multiflora).

\section{Luzula multiflora}

S1: Slovenia, Pohorje, Lovrenc na Pohorju, acidophilus grassland above the hut on Klopni vrh, $1,250 \mathrm{~m}, 15.3997222^{\circ} \mathrm{E}, 46.5019444^{\circ} \mathrm{N}, \mathrm{BF}$ and MT, 30.7.2005;

S9: Slovenia, Dolenjska, Kočevsko, alp Golobinjek NE of the village Koprivnik, forest margin, $900 \mathrm{~m}$,

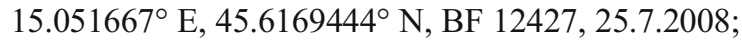

S10: Slovenia, Grosuplje, Radensko polje, $325 \mathrm{~m}$, $14.6847222^{\circ}$ E, 45.919444 ${ }^{\circ} \mathrm{N}, \mathrm{T}$. Bačič, 21.5.2009.

\section{Luzula exspectata}

S2: Slovenia, Kamniške Alpe, Raduha, $50 \mathrm{~m}$ above Durce, $1,900 \mathrm{~m}, 14.74889^{\circ} \mathrm{E}, 46.4158333^{\circ} \mathrm{N}, \mathrm{BF}, 2.9 .2005$;

S3: Slovenia, Kamniške Alpe, Kamniško sedlo, 1,870 $\mathrm{m}, 14.59556^{\circ} \mathrm{E}, 46.359444^{\circ} \mathrm{N}, \mathrm{BF}$ and PS, 1.9.2005; 
S13: Slovenia, Gorenjska, Karavanke, Košuta, N from the hut »Na Kofcah«, calcareous scree, 1,800 m, $14.326111^{\circ} \mathrm{E}, 46.42778^{\circ} \mathrm{N}, \breve{\mathrm{S}} \mathrm{N}, 3.8 .2008$;

S14: Slovenia, Gorenjska, Karavanke, Košuta, Toplar, alpine grassland, $2,000 \mathrm{~m}, 14.31667^{\circ} \mathrm{E}, 46.4313889^{\circ}$ N, ŠN, 1.8.2008;

S15: Slovenia, Gorenjska, Karavanke, Košuta, N from the hut $» \mathrm{Na} \mathrm{Kofcah}$ «, calcareous scree, $1,700 \mathrm{~m}, 14.3263889^{\circ} \mathrm{E}, 46.4269444^{\circ} \mathrm{N}, \breve{\mathrm{S} N}$, 3.8.2008;

S19: Slovenia, Gorenjska, Karavanke, Košuta, Malo Kladivo, rocky grassland, 2,000 m, ŠN, $14.3380556^{\circ}$ E, $46.435^{\circ} \mathrm{N}, 6.8 .2009$;

S21: Slovenia, Gorenjska, Karavanke, Košuta, NE from Planina Šija, rocky grassland, 1,600 m, $14.3386111^{\circ} \mathrm{E}$, 46.429444ํ N, ŠN , 5.8.2009;

S22: Slovenia, Julian Alps, Malo polje near Velo polje, humid grassland, 1,650 $\mathrm{m}, \breve{\mathrm{S} N}, 13.8569444^{\circ} \mathrm{E}$, 46.3552778 ${ }^{\circ} \mathrm{N}, 19.8 .2009$;

S23: Slovenia, Gorenjska, Karavanke, Košuta, Tegoška gora, rocky grassland, $1,900 \mathrm{~m}, 14.36444^{\circ} \mathrm{E}$,

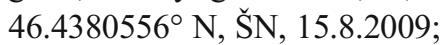

B6: NW Macedonia, Mt Šar planina, Popova Šapka Mali Jelak - Ceripašina (above the town Tetovo), 1,845-2,500 $\mathrm{m}$, subalpine meadow, $20.85556^{\circ} \mathrm{E}$, 42.008333 ${ }^{\circ}$ N, MT and BF 11967, 13.7.2005;

B9: Southern Macedonia, Pelister, Nižepole-Orlove bari, 1,800-2,150 m, acidic alpine meadow, 21.2097222 ${ }^{\circ}$ E, 40.9502778 N, BF and PS 11630, 21.8.2006;

B11: central Serbia, Kopaonik, northern slope of Mt Suvo Rudište, 1,750-1,850 m, acidic meadow, $20.8080556^{\circ} \mathrm{E}, 43.2869444^{\circ} \mathrm{N}, \mathrm{BF}$ and PS 11716 , 13.6.2006.

\section{Luzula taurica}

B7: Bosnia and Herzegovina, Bosnia, Čvrsnica: Mt Jelak above the lake Blidinje jezero, 1,350-1,550 m, subalpine meadows, $17.52^{\circ} \mathrm{E}, 43.59444^{\circ} \mathrm{N}, \mathrm{F}$. Bogunić, MT and BF 11799, 3.7.2005;

B8: Macedonia, Osogovske planine, western slopes of Mt Rujen, 1,800-2,250 m, acidic meadows on siliceous substrate, $22.5152778^{\circ} \mathrm{E}, 42.1580556^{\circ} \mathrm{N}, \mathrm{BF}$ and PS 11709, 14.6.2006;

B10: Montenegro, Komovi Mts., Kom Kučki: western and southern slopes, 1,900-2,487 m, acidified alpine meadows, limestone, $19.641667^{\circ} \mathrm{E}, 42.680556^{\circ} \mathrm{N}$, BF and PS 11586, 23.8.2006;

B16: Albania, Tropojë, Alpet Shqiptare, valley Valbona, along the path from Dragobi to the saddle W of Maja
Hekuraves, at the timberline, 1,611 m, lower alpine meadows, limestone, $19.9386111^{\circ} \mathrm{E}, 42.3997222^{\circ} \mathrm{N}$, PS, BF and DK 12983, 16.8.2010;

B17: Kosovo, Prokletije, Gjeravica/Đeravica, eastern ridge of Mala Đeravica, 2,211 m, relatively exposed alpine meadows with short snow cover over siliceous bedrock, $20.157222^{\circ} \mathrm{E}, 42.52778^{\circ} \mathrm{N}, \mathrm{PS}, \mathrm{BF}$ and DK 12951, 14.8. 2010;

B18: Bosnia and Herzegovina, Herzegovina, Prenj, along the path between alp Tisovica and Mt Lupoglav, 1,606 m, acidified subalpine meadow, limestone, $17.8627778^{\circ} \mathrm{E}, 43.568333^{\circ} \mathrm{N}, \mathrm{PS}, \mathrm{BF}$ and DK 12869 , 7.8.2010;

B19: Bosnia and Herzegovina, Herzegovina, Čvrsnica, alp Zaglavje along the path to Mt Veliki Vilinac, 1,559 $\mathrm{m}$, acidified pasture/meadow, limestone, $17.626111^{\circ} \mathrm{E}, 43.656111^{\circ} \mathrm{N}, \mathrm{PS}, \mathrm{BF}$ and DK 12882, 9.8.2010;

B20: Montenegro, Durmitor, saddle Mala previja S of Mt Terzin bogaz, 2,203 m, exposed alpine grassland, limestone, slightly acidified, $19.06222^{\circ} \mathrm{E}, 43.1191667^{\circ}$ N, PS, BF and DK 12906, 11.8.2010;

B21: Montenegro, W of Trešnjevik saddle KolašinAndrijevica, $1,572 \mathrm{~m}$, acidified meadow and forest margin, $19.68333^{\circ} \mathrm{E}, 42.7380556^{\circ} \mathrm{N}, \mathrm{PS}, \mathrm{BF}$ and DK 12915 , 12.8.2010;

B22: Montenegro, Komovi, upper Međukomlje, just below the saddle, $2,197 \mathrm{~m}$, slightly acidified, exposed alpine grasslands, limestone, $19.647222^{\circ} \mathrm{E}$, 42.6763889 ${ }^{\circ}$, PS, BF and DK 12929, 13.8.2010;

B24: Bosnia and Herzegovina, Bosna, Maglić, southern surroundings of Lokva Derneišta (SE of Dragoš sedlo), $1,758 \mathrm{~m}$, acidified subalpine meadow, limestone, $18.74778^{\circ}$ E, $43.2980556^{\circ}$ N, BF, PS and M. Falch 13770, 30.7.2013;

B25: Montenegro, Prokletije, Plav, Devojački krš S of the Čakor pass, $2,041 \mathrm{~m}$, grassland and pasture on silicate, $20.010833^{\circ} \mathrm{E}, 42.65778^{\circ} \mathrm{N}, \mathrm{BF}$ and PS 13992, 24.8.2014.

Undetermined specimens

B1: E Serbia, Bor, NNE slope of Mt Stol, 950-1,000 m, acidic meadow, $22.12667^{\circ} \mathrm{E}, 44.175^{\circ} \mathrm{N}, \mathrm{BF}$ and PS 11255, 20.6.2006;

B13: Bulgaria, Sofia, Vitoša, Aleko centre, S. Strgulc Krajšek, 23.6.2006;

B14: Bosnia and Herzegovina, Bosnia, Dinaric Mts, Troglav (saddle), 1,700 m, 16.6019444 ${ }^{\circ} \mathrm{E}$, 43.949444 $\mathrm{N}, \mathrm{BF}$, 17.7.2007. 
Appendix 2: Identification key for the Balkan species of Luzula sect. Luzula

1 Plants with or without underground stolons. Seeds (without caruncles, dorsal view) almost globular; the (dry) caruncle about half as long as the rest of the seed (Fig. 4 A, B) ...

1 * Plants without stolons. Seeds ovoid, oblong-ovoid or ellipsoidal; the caruncle about $1 / 6$ to $1 / 3$ as long as the rest of the seed (Fig. 4 C, D)........

2 Plants with underground stolons. Cauline leaves with almost smooth or sparsely papillose-serrate margin (2-5 papillae per $\mathrm{mm}$; $4 \overline{5 \mathrm{x} \text { magnification!); mostly }}$ at least one of the peduncles in the inflorescence recurved. Stomata (26) 29-38 (40) $\mu \mathrm{m}$.

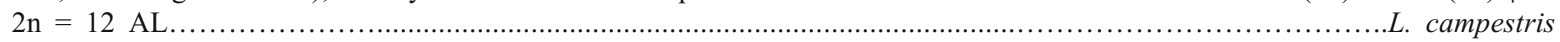

$2 *$ Plants without stolons. Cauline leaves with densely papillose-serrate margin (10-25 papillae per mm); all of the peduncles in the

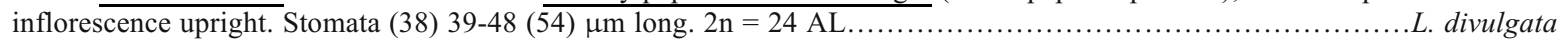

3 Anthers (fresh or refreshed in boiled water) about 1.6-3.5 $\mathrm{x}$ as long as their filaments (check more flowers from different clusters!). Stigma

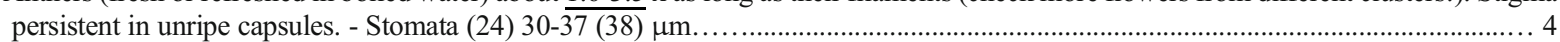

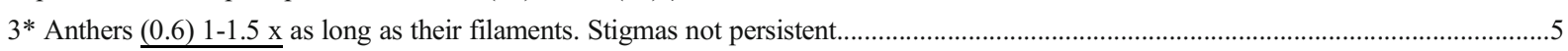

4 Clusters pale to medium brown, ripe capsule segments ca. 2-2.4 mm, seeds $0.8-0.9 \mathrm{~mm}$ wide; lowland species. $2 \mathrm{n}=24$

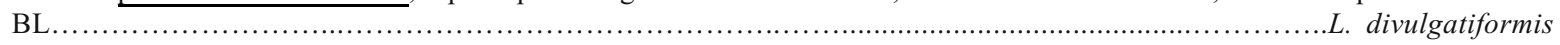

4* Clusters dark to blackish brown, ripe capsule segments ca. $2.4-3 \mathrm{~mm}$, seeds $0.7-0.8 \mathrm{~mm}$ wide; mountain species. $2 \mathrm{n}=12$

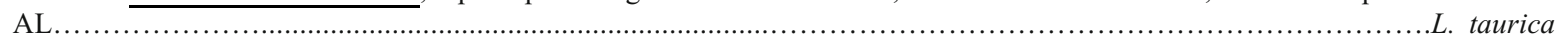

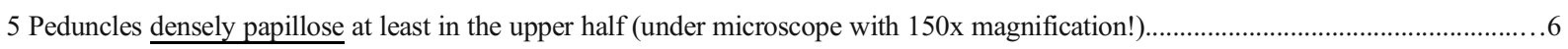

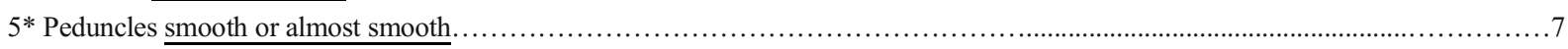

6 Clusters 7-18, ellipsoidal-cylindrical, with 9-20 flowers, often with secondary branches. Capsule segments 1.6-1.9 mm long. Seeds $0.7-0.8 \mathrm{~mm}$ long (measured from the dorsal view). Outer tepals conspicuously longer than the inner ones. $2 \mathrm{n}=12$

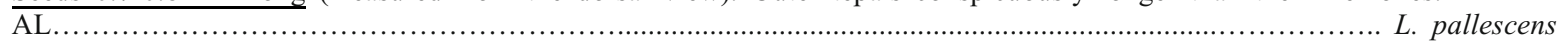

6* Clusters 3-7, ovoid to hemispherical, with 2-8 flowers, usually with secondary branches. Capsule segments $2-2.4$ mm long. Seeds $0.9-1 \mathrm{~mm}$ long. Outer tepals equal or slightly $(0.1-0.2 \mathrm{~mm})$ longer than the inner ones. $2 \mathrm{n}=24$

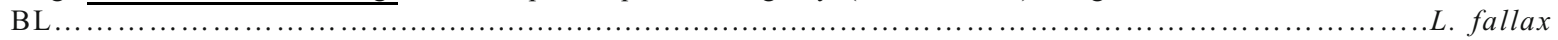

7 Outer tepals 2-2.5 (2.7) mm long. Anther filaments 0.4-0.5 mm long, styles 0.1-0.3 mm long (measured fresh or refreshed in boiled water). Seeds ellipsoidal (Fig. 4 D), 0.5-0.6 mm wide. Caruncles ca. $0.1 \mathrm{~mm}$ long. - Clusters blackish brown. $2 \mathrm{n}=$

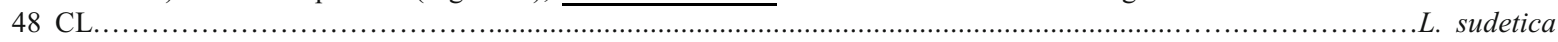

$7 *$ Outer tepals (2.3) 2.5-3.5 (4) mm long. Anther filaments 0.5-0.7 (0.8) mm long, styles (0.3) 0.4 - $0.9 \mathrm{~mm}$ long. Seeds ovoid, oblong-ovoid

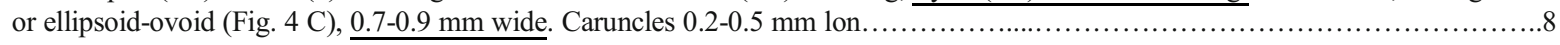

8 Inflorescence at least partly congested: subsessile clusters (1) 2-3 (inspect more flowering stems!). Tepals dark to blackish

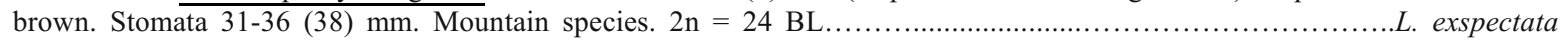

8* Inflorescence not congested: subsessile clusters 0-2. Tepals pale, medium or dark brown. Stomata (37) $39-48(54) \mathrm{mm}$. 2n = 24 AL, 36 AL.

.L. multiflora

Open Access This article is distributed under the terms of the Creative Commons Attribution 4.0 International License (http://creativecommons.org/licenses/by/4.0/), which permits unrestricted use, distribution, and reproduction in any medium, provided you give appropriate credit to the original author(s) and the source, provide a link to the Creative Commons license, and indicate if changes were made.

\section{References}

Bačič T, Dolenc Koce J, Jogan N (2007b) Luzula sect. Luzula (Juncaceae) in the South-Eastern Alps: morphology, determination and geographic distribution. Bot Helv 117:75-88 
Bačič T, Jogan N, Dolenc Koce J (2007a) Luzula sect. Luzula in the south-eastern Alps-karyology and genome size. Taxon 56:129136

Barina Z, Pifkó D, Mesterházy A (2011) Contributions to the flora of Albania, 3. Willdenowia 41:329-339

Barina Z, Rakaj M, Pifkó D (2013) Contributions to the flora of Albania, 4. Willdenowia 43:165-184

Barlow PW, Nevin D (1976) Quantitative karyology of some species of Luzula. Pl Syst Evol 125:77-86

Bennett MD, Leitch IJ (2012) Plant DNA C-values database (release 6.0, Dec. 2012). Available at: http://data.kew.org/ cvalues [Accessed: 18/10/2014]

Bogunić F, Muratović E, Brown SC, Siljak-Yakovlev S (2003) Genome size of five Pinus from Balkan region. Pl Cell Rep 22:59-63

Bogunić F, Siljak-Yakovlev S, Muratović E, Ballian D (2011a) Different karyotype patterns among allopatric Pinus nigra (Pinaceae) populations revealed by molecular cytogenetics. Pl Biol (Stuttgart) 13:194-200

Bogunić F, Siljak-Yakovlev S, Muratović E, Pustahija F, Medjedović S (2011b) Molecular cytogenetics and flow cytometry reveal conserved genome organization in Pinus mugo and P. uncinata. Ann For Sci 68:179-187

Bozek M, Leitch AR, Leitch IJ, Záveská Drábková L, E Kuta (2012) Chromosome and genome size variation in Luzula (Juncaceae), a genus with holocentric chromosomes. Bot J Linn Soc 170: 529-541

Drábková L, Kirschner J, Seberg O, Petersen G, Vlček Č (2003) Phylogeny of the Juncaceae based on $r b c \mathrm{~L}$ sequences, with special emphasis on Luzula DC. and Juncus L. Pl Syst Evol 240:133-147.

Drábková L, Kirschner J, Vlček Č (2006) Phylogenetic relationships within Luzula DC. and Juncus L. (Juncaceae): A comparison of phylogenetic signals of trnL-trnF intergenic spacer, $t r n \mathrm{~L}$ intron and $r b c \mathrm{~L}$ plastome sequence data. Cladistics 22:132-143.

Frajman B, Bačič T (2011) Contributions to the knowledge of the flora of Slovenia and adjacent regions: taxonomic revision and distributional patterns of ten selected species. Phyton (Horn) 50:231-262

Frajman B, Bačič T (2012) Prispevek k poznavanju flore Cerkniškega polja z okolico (Notranjska, Slovenija) [A contribution to the knowledge of the flora of Cerkniško polje and its vicinity (Notranjska region, Slovenia)]. Hladnikia (Ljubljana) 29:19-36

Frajman B, Carlón L, Kosachev P, Sánchez Pedraja O, Schneeweiss GM, Schönswetter P (2013) Phylogenetic position and taxonomy of the enigmatic Orobanche krylowii (Orobanchaceae), a predominatly Asian species newly found in Albania (SE Europe). Phytotaxa 137:1-14

Frajman B, Oxelman B (2007) Reticulate phylogenetics and phytogeographical structure of Heliosperma (Sileneae, Caryophyllaceae) inferred from chloroplast and nuclear DNA sequences. Molec Phylogen Evol 43:140-155
Frajman B, Pachschwöll C, Schönswetter P (2014) Contributions to the knowledge of the flora of Dinarides (Balkan Peninsula). Phyton (Horn) 54:27-46

Frajman B, Schneeweiss GM (2009) A campanulaceous fate: the Albanian stenoendemic Asyneuma comosiforme in fact belongs to isophyllous Campanula. Syst Bot 34:595-601

Frajman B, Schönswetter P (2008) Notes on some rare Orobanche and Phelipanche species (Orobanchaceae) in Croatia. Acta Bot Croat 67:103-107

Greilhuber J, Ebert I (1994) Genome size variation in Pisum sativum. Genome 37:646-655

Haizel T, Lim YK, Leitch AR, Moore G (2005) Molecular analysis of holocentric centromeres of Luzula species. Cytogenet Genome Res 109:134-143

Halkka O (1964) A photometric study of the Luzula problem. Hereditas 52:81-88

Heckmann S, Macas J, Kumke K, Jörg F, Schubert V, Ma L, Novák P, Neumann P, Taudien S, Platzer M, Houben A (2013) The holocentric species Luzula elegans shows interplay between centromere and large-scale genome organization. Pl J 73:555-565.

Heckmann S, Schroeder-Reiter E, Kumke K, Ma L, Nagaki K, Murata M, Wanner G, Houben A (2011) Holocentric chromosomes of Luzula elegans are characterized by a longitudinal centromere groove, chromosome bending, and a terminal nucleolus organizer region. Cytogenet Genome Res 134:220-228.

Hipp AL, Rothrock PE, Roalson EH (2009) The evolution and chromosome arrangements in Carex (Cyperaceae). Bot Rev 75:96-109

Horvat I, Glavač V, Ellenberg H (1974) Vegetation Südosteuropas. - G. Fischer, Stuttgart: pp 768

Husband BC, Baldwin SJ, Suda J (2013) The incidence of polyploidy in natural plant populations: major patterns and evolutionary processes. In Leitch IJ, Greilhuber J, Doležel J, Wendel JF (eds) Plant Genome Diversity. Springer, New York 2: pp 255-276

Kirschner J (1992a) Karyological differentiation of Luzula sect. Luzula in Europe. Thaiszia 2:11-39

Kirschner J (1992b) Luzula sect. Luzula (Juncaceae) in Spain. Pl Syst Evol 200:1-11

Kirschner J (1992c) Luzula sect. Luzula puzzle near Sofia, Bulgaria. Ann Bot Fenn 29:235-241

Kirschner J (1993) Taxonomic survey of Luzula sect. Luzula (Juncaceae) in Europe. Folia Geobot Phytotax 28:141-182

Kirschner J (1994) Luzula. In Fischer M (ed) Exkursionsflora von Österreich. Ulmer Verlag, Wien: pp 1080-1083

Kirschner J (1996) Tetraploid populations of Luzula multiflora subsp. multiflora (Juncaceae) in Europe. Preslia 67:219-223

Kirschner J (2002) Luzula. In Kirschner et al. Juncaceae 1: Rostkovia to Luzula, Species Plantarum: Flora of the World Part 6. National Library of Australia, Canberra: pp 18-188

Kryštufek B, Reed JM (2004) Pattern and processes in Balkan biodiversity - an overview. In Griffiths HI, Kryštufek B, Reed JM (eds) Balkan biodiversity, pattern and process in the European hotspot. Kluwer, Dordrecht: pp 203-217 
Kučera J, Marhold K, Lihová J (2010) Cardamine maritima group (Brassicaceae) in the amphi-Adriatic area: A hotspot of species diversity revealed by DNA sequences and morphological variation. Taxon 59:148-164

Kuta E, Bohanec B, Dubas E, Vižintin L, Przywara L (2004) Chromosome and nuclear DNA study on Luzula - a genus with holokinetic chromosomes. Genome 47:1-11

Kutnjak D, Kuttner M, Niketić M, Dullinger S, Schönswetter P, Frajman B (2014) Escaping to the summits: phylogeography and predicted range dynamics of Cerastium dinaricum, an endangered high mountain plant endemic to the western Balkan Peninsula. Molec Phylogen Evol 78:365-374

Lakušić D, Liber Z, Nikolić T, Surina B, Kovačić S, Bogdanović S, Stefanović S (2013) Molecular phylogeny of the Campanula pyramidalis species complex (Campanulaceae) inferred from chloroplast and nuclear non-coding sequences and its taxonomic implications. Taxon 62:505-524

Löve A, Löve D, Raymond M (1957) Cytotaxonomy of Carex section Capillares. Can J Bot 35:715-761

Luceño M, Guerra M (1996) Numerical variations in species exhibiting holocentric chromosomes: a nomenclatural proposal. Caryologia 49:301-309.

Madlung A (2013) Polyploidy and its effect on evolutionary success: old questions revisited with new tools. Heredity 110:99-104

Malheiros N, Gardé A (1950) Fragmentation as a possible evolutionary process in the genus Luzula DC. Genet Iber 2:257-262

Mello-Sampayo T (1961) Differential polyteny and karyotype evolution in 'Luzula', a critical interpretation of morphological and cytophotometric data. Genet Iber 13:1-22

Melters DP, Paliulis LV, Korf IF, Chan SWL (2012) Holocentric chromosomes: convergent evolution, meiotic adaptations, and genomic analysis. Chromosome Res 20:579-593

Milanović Đ, Brujić J, Stupar V (2011) Reports 64-72. Phytol Balcan 17:129-156

Mukherjee S, Sen J, Sharma AK (1993) Cytophotometric DNA estimation in Luzula species. Curr Sci India 65:987-989

Mullaj A, Shehu J, Tan K, Imeraj A (2010) New records for the Albanian flora. Bot Serbica 34:163-167

Muratović E, Hidalgo O, Garnatje T, Siljak-Yakovlev S (2010) Molecular phylogeny and genome size in European lilies (genus Lilium, Liliaceae). Advanced Sci Lett 3:180-189

Nagaki K, Kashihara K, Murata M (2005) Visualization of diffuse centromeres with centromere-specific histone $\mathrm{H} 3$ in the holocentric plant Luzula nivea. Pl Cell 17:1886-1893

Niketić M, Siljak-Yakovlev S, Frajman B, Lazarević M, Stevanović B, Tomović G, Stevanović V (2013) Towards resolving the systematics of Cerastium subsection Cerastium (Caryophyllaceae): a cytogenetic approach. Bot $J$ Linn Soc 172:205-224

Nordenskiöld H (1951) Cytotaxonomical studies in the genus Luzula. I. Somatic chromosomes and chromosome numbers. Hereditas 37:325-355

Nordenskiöld H (1956) Cytotaxonomical studies in the genus Luzula. II. Hybridisation experiments in the Luzula campestris-multiflora complex. Hereditas 42:7-73
Pazy B, Plitmann U (1995) Chromosome divergence in the genus Cuscuta and its systematic implications. Caryologia 48: 173-180

Ramsey J, Schemske DW (1998) Pathways, mechanisms and rates of polyploid formation in flowering plants. Annual Rev Ecol Syst 29:4676-4501

Renny-Byfield S, Kovarik A, Kelly LJ, Macas J, Novak P, Chase MW, Nichols RA, Pancholi MR, Grandbastien MA, Leitch AR (2013) Diploidization and genome size change in allopolyploids is associated with differential dynamics of lowand high-copy sequences. Pl J 74:829-839.

Rešetnik I, Frajman B, Bogdanović S, Ehrendorfer F, Schönswetter P (2014) Disentangling relationships among the diploid members of the intricate genus Knautia (Caprifoliaceae, Dipsacoideae). Molec Phylogen Evol 74:97-110

Sánchez-Jiménez I, Hidalgo O, Ángel Canela M, Siljak-Yakovlev S, Edita Šolić M, Vallès J, Garnatje T (2012) Genome size and chromosome number of Echinops (Asteraceae, Cardueae) in the Aegean and Balkan regions: technical aspects of nuclear DNA amount assessment and genome evolution in a phylogenetic frame. Pl Syst Evol 298:1085-1099

Sen J, Mukherjee S, Sharma AK (1990) Study of chromosomes, DNA amount and in vitro growth in different species of Luzula. Genome 33:143-147

Siljak-Yakovlev S, Pustahija F, Šolić EM, Bogunić F, Muratović E, Basić N, Catrice O, Brown SC (2010) Towards a genome size and chromosome number database of Balkan Flora: Cvalues in 343 taxa with novel values for 242. Advanced Sci Lett 3:190-213

Siljak-Yakovlev S, Šolić ME, Catrice O, Brown SC, Papes D (2005) Nuclear DNA content and chromosome number in some diploid and tetraploid Centaurea (Asteraceae: Cardueae) from the Dalmatia region. Pl Biol 7:397-404

Siljak-Yakovlev S, Stevanović V, Tomašević M, Brown SC, Stevanović B (2008) Genome size variation and polyploidy in the resurrection plant genus Ramonda: cytogeography of living fossils. Environm Exp Bot 62:101-112

Šmarda P, Bureš P, Horová L, Leitch IJ, Mucina L, Pacini E, Tichý L, Grulich V, Rotreklová O (2014) Ecological and evolutionary significance of genomic GC content diversity in monocots. Proc Natl Acad Sci USA 111:E4096-4102

Soltis DE, Albert VA, Leebens-Mack J, Bell CD, Paterson AH, Zheng C, Sankoff D, dePamphilis CW, Wall PK, Soltis PS (2009) Polyploidy and angiosperm diversification. Amer $J$ Bot 96:336-348

Stefanović S, Lakušić D, Kuzmina M, Međedović S, Tan K, Stevanović V (2008) Molecular phylogeny of Edraianthus (Grassy Bells; Campanulaceae) based on non-coding plastid DNA sequences. Taxon 57:452-475

Stevanović V, Tan K, Petrova A (2007) Mapping the endemic flora of the Balkans a progress report. Bocconea 21:131-137

Surina B, Schönswetter P, Schneeweiss GM (2011) Quaternary range dynamics of ecologically divergent species (Edraianthus serpyllifolius and E. tenuifolius, Campanulaceae) within the Balkan refugium. J Biogeogr 38:1381-1393

Surina, B. Schneeweiss, GM, Glasnović P, Schönswetter P (2014) Testing the efficiency of nested barriers to 
dispersal in the Mediterranean high mountain plant Edraianthus graminifolius (Campanulaceae). Molec Ecol 23:2861-2875

Tomović G, Niketić M, Lakušić D, Ranđelović V, Stevanović V (2014) Balkan endemic plants in Central Serbia and Kosovo regions: distribution patterns, ecological characteristics, and centres of diversity. Bot J Linn Soc 176:173-202

Verma SC, Rees H (1974) Nuclear DNK and evolution of allotetraploid Brassicaceae. Heredity 33:61-68.
Vilhar B, Greilhuber J, Dolenc Koce J, Temsch EM, Dermastia M (2001) Plant genome size measurement with DNA image cytometry. Ann Bot (Oxford) 87:531-546

Weiss-Schneeweiss H, Emadzade K, Jang TS, Schneeweiss GM (2013) Evolutionary consequences, constraints and potential of polyploidy in plants. Cytogenet Genome Res 140:137-150

Wood TE, Takebayashi N, Barker MS, Mayrose I, Greenspoon PB, Rieseberg LH (2009) The frequency of polyploid speciation in vascular plants. Proc Natl Acad Sci USA 106:1387513879 